\title{
Ovarian function in ewes after treatment with mifepristone early during the oestrous cycle
}

\author{
E. M. Paslay, J. R. Jaeger, U. Salli and F. Stormshak* \\ Department of Animal Sciences, Oregon State University, Corvallis, OR 97331-6702, USA
}

\begin{abstract}
The aim of this study was to determine whether endogenous progesterone regulates synthesis and secretion of luteal oxytocin. In Expt 1, mature ewes ( $n=5$ per group) were assigned randomly to control or mifepristone (RU486) treatment groups. Ewes were injected s.c. twice a day with vehicle or $10 \mathrm{mg}$ RU486 on days 5-7 of the oestrous cycle (oestrus $=$ day 0 ). On day 8 , after an i.v. injection with prostaglandin $F_{2 \alpha}(250 \mu g$ cloprostenol), venous blood samples were collected at frequent intervals to determine plasma oxytocin concentrations. Plasma oxytocin concentrations of RU486-treated ewes were not significantly different from those of control ewes. In Expt 2, ewes were injected s.c. each day with vehicle or $175 \mathrm{mg}$ RU486 on days 2-5 of the oestrous cycle followed by administration
\end{abstract}

of prostaglandin $F_{2 \alpha}$ on day 6 . Four of five RU486-treated ewes showed 'split-oestrus' (oestrous behaviour for $36 \mathrm{~h}$ and then again at 84-108 $\mathrm{h}$ after the onset of initial oestrus). There was no significant difference in mean plasma oxytocin or progesterone concentrations between treatment groups. The mean masses of mature corpora lutea from control and RU486-treated ewes on day 6 of the oestrous cycle did not differ significantly (394.8 $\pm \mathbf{2 8 . 8}$ versus $319.5 \pm 48.3 \mathrm{mg}$ ). RU486-treated ewes contained mature corpora lutea, new corpora lutea (two of four ewes) and preovulatory follicles ( $\geq 10 \mathrm{~mm}$, two of four ewes). The average interoestrous interval for RU486-treated ewes was 9 days more than that for control animals $(26.2 \pm 2.9$ versus $17 \pm 0.5$ days; $P<0.025$ ).

\section{Introduction}

It is well known that oxytocin is produced by the hypothalamus, stored in the posterior pituitary gland and secreted upon appropriate stimulation. More recently it has been established that oxytocin is also synthesized and secreted by the ruminant corpus luteum during the oestrous cycle (Wathes and Swann, 1982; Flint et al., 1990). Administration of prostaglandin $\mathrm{F}_{2 \alpha}\left(\mathrm{PGF}_{2 \alpha}\right)$ to cows and ewes causes a transient increase in plasma oxytocin concentrations, which in some studies has been shown to be associated with induction and promotion of luteal regression (Flint and Sheldrick, 1982; Schallenberger et al., 1984; Flint et al., 1990; Orwig et al., 1994; Salli et al., 2000).

The oxytocin gene is actively transcribed in the bovine and ovine corpus luteum (Ivell and Richter, 1984; Ivell et al., 1985; Jones and Flint, 1988). Although bovine granulosa cells appear to contain a low oxytocin mRNA content, gene transcription is upregulated on the day of ovulation to yield 100-fold more mRNA by day 3 of the oestrous cycle (Ivell et al., 1985). There is no significant positive correlation between the concentrations of oxytocin mRNA and the peptide within the corpus luteum throughout the mid-oestrous cycle

*Correspondence

Email: Fred.Stormshak@orst.edu
(Fehr et al., 1987). After day 3, luteal concentrations of oxytocin mRNA gradually decrease over the course of the oestrous cycle (Ivell et al., 1985; Jones and Flint, 1988), whereas maximum luteal production of oxytocin in cows and ewes occurs during the mid-oestrous cycle followed by a decrease in production (Sheldrick and Flint, 1983; Abdelgadir et al., 1987). Thus, peak luteal oxytocin production lags behind that of oxytocin mRNA by 3-6 days but does coincide with maximum synthesis of progesterone (Webb et al., 1981; Fehr et al., 1987).

Progesterone receptor mRNA, and the receptor protein have been identified in ovine and bovine preovulatory follicles and corpora lutea (Smith et al., 1995; Bolden-Tiller et al., 2002). Because luteal concentrations of progesterone receptor mRNA and the receptor coincide with the increase in luteal oxytocin mRNA and oxytocin production (Jones and Flint, 1988; Smith et al., 1995), it is conceivable that progesterone may be acting in an autocrine manner to promote oxytocin synthesis and secretion in the ovine corpus luteum. This premise is supported by Voss and Fortune (1993) who reported that progesterone stimulated oxytocin secretion by bovine granulosa cells during the late stages of a 5 day culture. Similarly, when bovine granulosa cells were cultured with progesterone antagonists mifepristone (RU486) and onapristone, oxytocin secretion was significantly reduced and this effect could be reversed by the presence 
of a progestagen (Lioutas et al., 1997). Therefore, the objective of the present study was to determine whether the antagonistic actions of RU486 in the ewe lead to decreased luteal oxytocin synthesis and secretion during the early stages of the oestrous cycle.

\section{Materials and Methods}

\section{Animals}

Mature Polypay ewes (3-5 years of age, weighing 65$82 \mathrm{~kg}$ ) with normal oestrous cycles ( $17 \pm 1$ days) were assessed for signs of oestrous behaviour twice a day with a vasectomized ram; the first day of observed oestrus was designated as day 0 of the oestrous cycle. Ewes were assigned randomly to treatment groups before the beginning of the study.

Ewes were anaesthetized with an i.v. injection of $5 \%(\mathrm{w} / \mathrm{v})$ sodium pentothal (Abbott Laboratories, $\mathrm{N}$. Chicago, IL) followed by maintenance of anaesthesia by use of closed circuit inhalation of an oxygenhalothane mixture (Halocarbon Laboratories, River Edge, $\mathrm{NJ})$ to collect luteal tissue from ewes on day 6 and day 8 of the oestrous cycle. The reproductive organs were exposed through a mid-ventral abdominal incision. Luteal tissues were enucleated from the ovaries and immediately stored on ice until weighed. Follicles (5$10 \mathrm{~mm}$ in diameter) were left intact, measured in situ and details recorded. Intramuscular injections of banamine (Schering-Plough Animal Health Corp., Union, NJ; $50 \mathrm{mg} \mathrm{m}^{-1}$ ) and penicillin $\mathrm{G}$ procaine (Butler Co., Columbus, $\mathrm{OH} ; 300000$ units $\mathrm{ml}^{-1}$ ) were administered immediately after surgery. All experimental procedures and protocols were reviewed and performed in accordance with the institutional Animal Care and Use Committee guidelines at Oregon State University.

\section{Experiment 1}

Luteal oxytocin synthesis. Ewes $(n=5)$ were injected s.c. twice a day with $10 \mathrm{mg}$ RU486 (Sigma Chemical Co., St Louis, MO) dissolved in $10 \mathrm{ml}$ corn oil on days $5-7$ of the oestrous cycle. Control ewes $(n=5)$ were injected with corn oil only. On day 8, all ewes received an i.v. injection of $\mathrm{PGF}_{2 \alpha}(250 \mu \mathrm{g}$ cloprostenol, ScheringPlough Animal Health Corp.). Blood samples were collected at -15 and $0 \mathrm{~min}$ to establish the basal secretion of oxytocin, and at 2.5, 5.0, 10.0, 15.0, 20.0, 30.0 and 40.0 min after $\mathrm{PGF}_{2 \alpha}$ administration. All blood samples were collected into $10 \mathrm{ml}$ heparinized vacutainer tubes (Becton Dickinson Vacutainer Systems, Franklin Lakes, NJ) and EDTA $\left(0.5 \mathrm{~mol} \mathrm{I}^{-1} ; 20 \mu \mathrm{l}\right)$ and 1,10 phenanthroline $\left(5 \mathrm{mg} \mathrm{ml}^{-1}\right.$ in ethanol; $\left.10 \mu \mathrm{l}\right)$ were added immediately to block endogenous oxytocinase activity; the tubes were then stored on ice until use. Blood samples were centrifuged at $1650 \mathrm{~g}$ for $12 \mathrm{~min}$ at $4^{\circ} \mathrm{C}$, and plasma was stored at $-20^{\circ} \mathrm{C}$ until assayed for oxytocin. Plasma from the samples collected at $15 \mathrm{~min}$ before the administration of $\mathrm{PGF}_{2 \alpha}$ was also assayed for progesterone by use of radioimmunoassay.

Ovarian morphology. Ewes were assigned randomly to two treatment groups: (i) control $(n=4)$ and (ii) RU486 treatment $(n=4)$ to evaluate the effects of RU486 on ovarian function and morphology. Ewes received s.c. injections twice each day of either $10 \mathrm{mg}$ RU486 dissolved in corn oil or $10 \mathrm{ml}$ corn oil only. Ewes were injected on days 5-7 of the oestrous cycle. On day 8, control and treated animals were anaesthetized and luteal tissue was collected as described above.

\section{Experiment 2}

Luteal oxytocin synthesis. Ewes $(n=5)$ were injected s.c. once a day with $175 \mathrm{mg}$ RU486 (Sigma) dissolved in $10 \mathrm{ml}$ corn oil on days $2-5$ of the oestrous cycle. Control ewes $(n=5)$ were injected with corn oil only. On day 6 , ewes received an i.v. injection of $\mathrm{PGF}_{2 \alpha}(250 \mu \mathrm{g}$ cloprostenol). Blood samples were collected at frequent intervals as in Expt 1 for up to 60 min after administration. One sample was collected before administration of $\mathrm{PGF}_{2 \alpha}$ to determine plasma progesterone concentrations. All blood samples were collected into $10 \mathrm{ml}$ heparinized vacutainer tubes (Becton Dickinson Vacutainer Systems) and for samples collected for oxytocin analysis EDTA and 1,10 phenanthroline were added immediately and the tubes were then placed on ice for transport to the laboratory. Blood samples were centrifuged at $1650 \mathrm{~g}$ for 12 min at $4{ }^{\circ} \mathrm{C}$, and plasma was stored at $-20^{\circ} \mathrm{C}$ until assayed for oxytocin and progesterone.

Ovarian morphology. Ewes were assigned randomly to two treatment groups: (i) control $(n=4)$ and (ii) RU486 $(n=4)$ to evaluate the effects of RU486 on ovarian function and morphology. Ewes received s.c. injections of either $175 \mathrm{mg}$ RU486 dissolved in corn oil or $10 \mathrm{ml}$ corn oil only. Ewes were injected once each day on days $2-5$ of the oestrous cycle. On day 6, control and RU486treated animals were anaesthetized, and luteal tissue was collected and follicle diameters measured as described above.

Oxytocin radioimmunoassay. Oxytocin was extracted from $1 \mathrm{ml}$ plasma and measured by radioimmunoassay using methods adapted from Schams (1983) and Abdelgadir et al. (1987), using an oxytocin antibody $(1: 7000)$ generously provided by D. Schams (Technical University of Munich). The mean extraction efficiency was $63 \%$ as determined by the addition of $\left[{ }^{3} \mathrm{H}\right]$ oxytocin (4 000 c.p.m. per $100 \mu \mathrm{l} ; 2200 \mathrm{Ci} \mathrm{mmol}^{-1}$; New England Nuclear, Boston, MA). Plasma concentrations of oxytocin determined by radioimmunoassay were corrected for losses due to extraction. Plasma samples of $100 \mu \mathrm{l}$ per tube were used in the radioimmunoassay. The 
sensitivity of the assay was $1 \mathrm{pg} \mathrm{ml}^{-1}$. All samples were analysed in three consecutive assays and the intra- and interassay coefficients of variation were 2.78 and $7.02 \%$, respectively.

Progesterone radioimmunoassay. Plasma concentrations of progesterone were assayed by radioimmunoassay as described by Koligian and Stormshak (1976). Plasma progesterone was extracted from $100 \mu$ l plasma with benzene: hexane $(1: 2)$. $\left[1,2,6,7-^{3} \mathrm{H}\right]$ progesterone (4000 c.p.m. per $100 \mu \mathrm{l}$; $44.5 \mathrm{Ci} \mathrm{mmol}^{-1}$; New England Nuclear) was added to a third tube containing an aliquot of plasma to correct for procedural loss due to extraction. The mean extraction efficiency was $88 \%$.

Extracted samples were quantified by radioimmunoassay using the 337 anti-progesterone-11-BSA $(1: 2400)$ provided by G. D. Niswender (Colorado State University). All samples were analysed in two consecutive assays and the intra- and interassay coefficients of variation were 1.9 and $8.4 \%$, respectively. The sensitivity of the assay was $10 \mathrm{pg} \mathrm{ml}^{-1}$.

\section{Statistical analysis}

Plasma concentrations of oxytocin were analysed by use of repeated measures ANOVA. Data on luteal masses were analysed by analysis of covariance using the number of corpora lutea as the independent variable, and plasma concentrations of progesterone were analysed by one-way ANOVA.

\section{Results}

\section{Experiment 1}

Luteal oxytocin synthesis. Treatment of ewes with 10 mg RU486 twice a day on days 5-7 of the oestrous cycle did not result in a significant decrease in luteal oxytocin concentrations compared with those of control ewes after the administration of $\mathrm{PGF}_{2 \alpha}$ (Fig. 1). Mean plasma concentrations of progesterone before the administration of $\mathrm{PGF}_{2 \alpha}$ on day 8 of the oestrous cycle did not differ significantly $(P=0.14)$ between RU486treated and control ewes $(3.06 \pm 0.27$ versus $2.16 \pm$ $0.35 \mathrm{ng} \mathrm{ml}^{-1}$, respectively).

Ovarian morphology. Mean masses of mature corpora lutea in control and RU486-treated ewes did not differ significantly $(372.6 \pm 32.6$ versus $397.2 \pm 27.4 \mathrm{mg}$, respectively). After administration of $\mathrm{PGF}_{2 \alpha}$, all control ewes displayed signs of oestrus within $48 \mathrm{~h}$. However, only three of five RU486-treated ewes displayed signs of oestrus within $48 \mathrm{~h}$ after $\mathrm{PGF}_{2 \alpha}$ administration; the remaining two ewes had not responded by $96 \mathrm{~h}$ after injection of $\mathrm{PGF}_{2 \alpha}$.

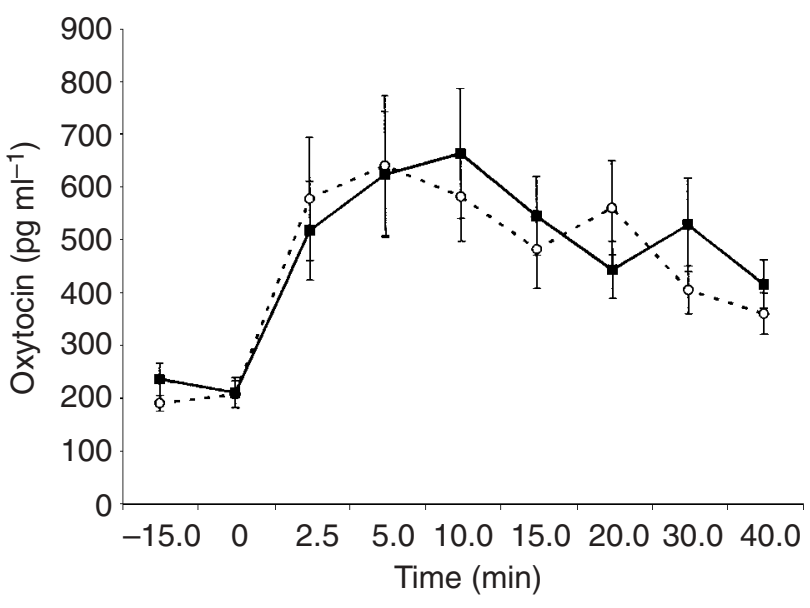

Fig. 1. Mean $( \pm \mathrm{SE})$ systemic plasma concentrations of oxytocin in ewes treated with corn oil $(\bigcirc, n=5)$ or $10 \mathrm{mg} \operatorname{RU} 486(\boldsymbol{\square}, n=5)$ twice a day on days $5-7$ of the oestrous cycle after administration of prostaglandin $\mathrm{F}_{2 \alpha}$ on day 8 ( $0 \mathrm{~min}$ ) of the oestrous cycle.

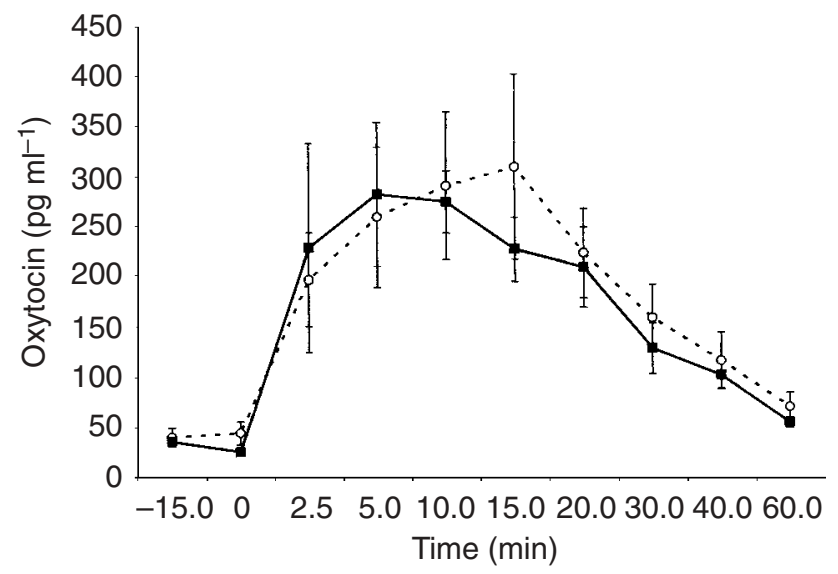

Fig. 2. Mean $( \pm S E)$ systemic plasma concentrations of oxytocin in ewes treated with corn oil $(\bigcirc, n=5)$ or $175 \mathrm{mg} \operatorname{RU} 486(\boldsymbol{\square}, n=5)$ on days $2-5$ of the oestrous cycle after administration of prostaglandin $\mathrm{F}_{2 \alpha}$ on day $6(0 \mathrm{~min})$ of the oestrous cycle.

\section{Experiment 2}

Luteal oxytocin synthesis. Treatment of ewes with $175 \mathrm{mg}$ RU486 on days 2-5 of the oestrous cycle did not result in a significant change in $\mathrm{PGF}_{2 \alpha}$-induced luteal oxytocin secretion compared with those of control ewes (Fig. 2). Administration of $\mathrm{PGF}_{2 \alpha}$ on day 6 did not cause luteal regression or a shortened oestrous cycle in control or RU486-treated ewes. Control ewes displayed a normal interoestrous interval of $17 \pm 0.5$ days. After the initiation of treatments, four of five RU486-treated ewes showed signs of a subsequent oestrus, observed as early as $48 \mathrm{~h}$ after the end of the original oestrus (Fig. 3). Mean plasma concentrations of progesterone in RU486-treated animals did not differ significantly from those of the control animals $(0.92 \pm 0.04$ versus 0.94 $\pm 0.07 \mathrm{ng} \mathrm{ml}^{-1}$, respectively). 
Table 1. Ovarian characteristics of RU486-treated and control ewes

\begin{tabular}{|c|c|c|c|c|c|c|}
\hline Group & (n) & $\begin{array}{c}\text { Number of } \\
\text { day } 6 \mathrm{CL}\end{array}$ & $\begin{array}{c}\text { Average }( \pm \mathrm{SE}) \\
\text { mass of } \\
\text { day } 6 \mathrm{CL}(\mathrm{mg})^{*}\end{array}$ & $\begin{array}{c}\text { Number of } \\
\text { new CL }\end{array}$ & $\begin{array}{l}\text { Average }( \pm \text { SE) } \\
\text { follicle diameter } \\
\qquad(\mathrm{mm})^{\dagger}\end{array}$ & $\begin{array}{c}\text { Average }( \pm \mathrm{SE}) \\
\text { interoestrous } \\
\text { interval }^{\ddagger}\end{array}$ \\
\hline Control & 5 & 6 & $394.8 \pm 28.8^{a}$ & 0 & $7 \pm 0.26$ & $17.0 \pm 0.5^{\mathrm{a}}$ \\
\hline Treated & 5 & 9 & $319.5 \pm 48.3^{a}$ & 5 & $9 \pm 0.58$ & $26.2 \pm 2.9^{b}$ \\
\hline
\end{tabular}

* Data were analysed by analysis of covariance.

†Two RU486-treated ewes had four follicles with a diameter $\geq 10 \mathrm{~mm}$.

$\ddagger$ Interoestrous interval was determined from the onset of the original observed oestrus to the onset of the next normal oestrous cycle.

a,b Means with a different superscript are significantly different $(P<0.025)$.

$\mathrm{CL}$ : corpus luteum.

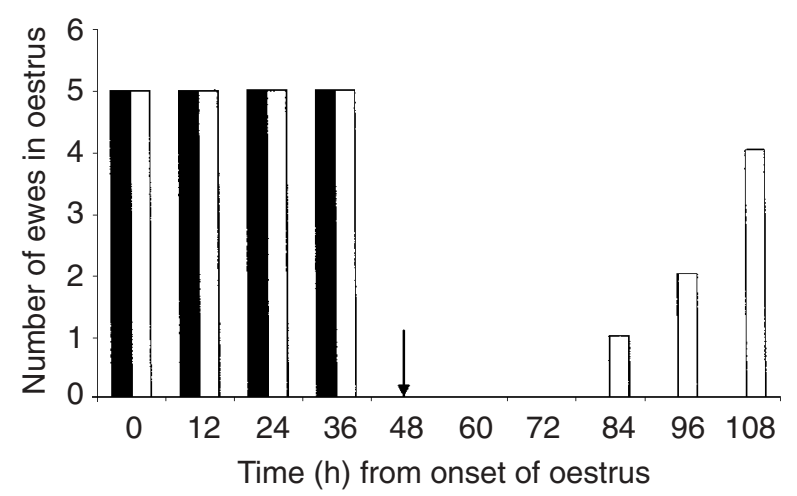

Fig. 3. Oestrous behaviour of ewes treated each day with corn oil $(\square, n=5)$ or $175 \mathrm{mg} \mathrm{RU} 486(\square, n=5)$ during the early luteal phase of the oestrous cycle. Treatments were administered at $48 \mathrm{~h}$ (arrow) after the onset of the original oestrus and continued throughout the treatment period. Four of five ewes showed signs of oestrus for a second time between 36 and $60 \mathrm{~h}$ after the initial injection of RU486.

Ovarian morphology. Mean masses of mature corpora lutea in control and RU486-treated ewes did not differ significantly $(394.8 \pm 28.8$ versus $319.5 \pm 48.3 \mathrm{mg}$, respectively). RU486-treated ewes had new corpora lutea (corpora haemorrhagica) or preovulatory follicles $(10 \mathrm{~mm}$ in diameter), or both, in addition to mature corpora lutea (Table 1). The average interoestrous interval for RU486-treated ewes was 9 days more than, and was significantly different from $(\mathrm{P}<0.025)$ that of the control animals (17 \pm 0.5 versus $26.2 \pm 2.9$ days; Table 1$)$.

\section{Discussion}

Administration of comparatively low and high dosages of RU486 to ewes during the early to mid-luteal phase of the oestrous cycle did not affect oxytocin synthesis or secretion and did not alter systemic concentrations of progesterone. Regardless of whether the ewes received $\mathrm{PGF}_{2 \alpha}$ on day 6 or day 8 of the oestrous cycle, both control and RU486-treated ewes responded to exogenous $\mathrm{PGF}_{2 \alpha}$ with a maximum release of oxytocin detected within 2.5 min after injections. The observed response to $\mathrm{PGF}_{2 \alpha}$ was similar to those reported by Orwig et al. (1994) and Salli et al. (2000). The systemic concentrations of luteal oxytocin are substantially lower on day 6 , during the early luteal phase, than on day 8 of the oestrous cycle. Systemic oxytocin concentrations after the administration of $\mathrm{PGF}_{2 \alpha}$ during the early and mid-luteal phase are also consistent with values observed in the utero-ovarian venous blood of ewes within the same time period (Hooper et al., 1986).

Neither control nor RU486-treated ewes injected with $\mathrm{PGF}_{2 \alpha}$ on day 6 had a shortened oestrous cycle. Failure of the administration of $\mathrm{PGF}_{2 \alpha}$ to result in a shortened oestrous cycle may have been due to the refractoriness of the corpora lutea to this eicosanoid early in the luteal phase (Acritopoulou and Haresign, 1980). However, control and RU486-treated ewes that received $\mathrm{PGF}_{2 \alpha}$ on day 8 of the oestrous cycle showed signs of behavioural oestrus within $48 \mathrm{~h}$.

Although unexpected, the results of the present study indicate that treatment with RU 486 during metoestrus results in a 'split oestrus'. This split oestrus was observed in four of five ewes that received two injections of $175 \mathrm{mg}$ RU486 within $84 \mathrm{~h}$ after the onset of initial observed oestrus. This result was not observed in ewes that received the lower dose of RU486 on days 5-7 of the oestrous cycle in Expt 1. Similarly, split oestrus was not reported by Morgan et al. (1993) who injected ewes with $2.5 \mathrm{mg} \mathrm{RU} 486 \mathrm{~kg}^{-1}$ each day on days $5-8$ of the oestrous cycle. These workers also observed the maintenance of original corpus lutuem on day 15 in RU486-treated ewes but no additional ovulations or accessory corpora lutea were detected. In a concurrent study in our laboratory, $150 \mathrm{mg}$ RU486 administered to ewes at the onset of oestrus, and 24 and $48 \mathrm{~h}$ later, resulted in the same phenomenon of split oestrus in three of five RU486treated ewes within $96 \mathrm{~h}$ after onset of the original oestrus (A. Wurst, unpublished).

These observations of split oestrus may be attributed to the antagonistic actions of RU486 at the hypothalamus. RU486 is a potent anti-progestin in reproductive tissues, as well as in the central nervous system (Philbert, 1984). In studies conducted in female rat hypothalamus, RU486 bound with very high affinity to progesterone 
receptors, particularly in the preoptic nuclei (Pleim et al., 1990). Thus, it is conceivable that RU486 may be binding to progesterone receptors in the hypothalamus, blocking the negative feedback inhibition of endogenous progesterone (Skinner et al., 1999) and encouraging the maturation of the next follicular wave with consequent secretion of oestrogen in sufficient quantities to elicit oestrous behaviour.

Ovarian morphology of ewes that received $175 \mathrm{mg}$ RU486 revealed the presence of mature corpora lutea, new sites of ovulation and preovulatory follicles that occurred in various combinations in individual ovaries. It has been observed that ewes treated with RU486 during the early luteal phase resulted in additional $\mathrm{LH}$ surges within hours after the initial ovulatory LH surge (Campbell et al., 2000). These researchers concluded that the subsequent $\mathrm{LH}$ surges resulted from the positive feedback action of oestradiol derived from developing follicles, which is consistent with the findings of our morphological studies.

The interoestrous interval was extended in ewes that received $175 \mathrm{mg}$ RU486 each day from day 2 to day 5 of the oestrous cycle. The 9 day extension of the oestrous cycle in these ewes compared with that of the control ewes may be attributed to the formation of new corpora lutea at the split oestrus, which were able to remain functional for the duration of a normal oestrous cycle. However, it is also conceivable that the lifespan of the original corpus luteum was extended. According to Morgan et al. (1993), treatment of ewes with RU486 from day 5 to day 8 interfered with the normal timing of luteolysis by causing a delay in the onset of a pulsatile pattern of $\mathrm{PGF}_{2 \alpha}$ secretion by the uterus. Failure of luteolysis to occur was supported by the finding that plasma concentrations of progesterone were significantly greater in RU486-treated ewes than in control ewes on days 16, 18, 20 and 22 after oestrus.

RU486 administration during the early luteal phase of the oestrous cycle appears to be a powerful antagonist at the hypothalamus, and perhaps the uterus. It has been proposed that progesterone acts in an autocrine manner to regulate its synthesis, ultimately affecting its paracrine actions and regulation of other hormones (Rothchild, 1981, 1996). Although the highest dosage of RU486 used in the present study was apparently able to block the negative feedback of progesterone at the hypothalamo-hypophyseal axis, it was not able to induce or sustain a marked reduction in luteal function. Progesterone has been shown to stimulate oxytocin secretion by granulosa cells in vitro (Voss and Fortune, 1993), whereas RU486 suppressed the production of this nonapeptide by cultured granulosa cells (Lioutas et al., 1997). Thus, failure of RU486 to effect a detectable change in luteal oxytocin production in the present study may be attributable to the presence of an insufficient quantity of the progesterone antagonist in the corpus luteum. Further studies are required to examine the autocrine action of progesterone in regulating ovine luteal oxytocin synthesis using a methodological approach to ensure that the corpus luteum is exposed to an increased quantity of RU486 through mid-oestrous cycle.

This is technical paper no. 11911, Oregon Agricultural Experiment Station. The authors thank K. Dunlap and J. Schrunk for their help throughout the course of this research.

\section{References}

Abdelgadir SE, Swanson LV, Oldfield JE and Stormshak F (1987) Prostaglandin $\mathrm{F}_{2 \alpha}$-induced release of oxytocin from bovine corpora lutea in vitro. Biology of Reproduction 37 550-555

Acritopoulou S and Haresign W (1980) Response of ewes to a single injection of an analogue of $\mathrm{PGF}_{2 \alpha}$ given at different stages of the oestrous cycle Journal of Reproduction and Fertility 58 219-223

Bolden-Tiller OU, Lucy MC, Rucker EB and Smith MF (2002) Bovine luteal progesterone receptor: a modulator of progesterone in bovine corpora lutea? Biology of Reproduction 66 Supplement 1 183-184

Campbell BK, de Souza C and Baird DT (2000) Progesterone as a cycle organizer: mifepristone causes ovulation of first wave follicles in sheep Journal of Reproduction Fertility Abstract Series $\mathbf{2 6} 4$

Fehr S, Ivell R, Koll R, Schams D, Fields M and Richter D (1987) Expression of the oxytocin gene in the large cells of the bovine corpus luteum FEBS Lett 210 45-50

Flint APF and Sheldrick EL (1982) Ovarian secretion of oxytocin is stimulated by prostaglandin Nature 297 587-588

Flint APF, Sheldrick EL, McCann TJ and Jones DSC (1990) Luteal oxytocin: characteristics and control of synchronous episodes of oxytocin and $\mathrm{PGF}_{2 \alpha}$ secretion at luteolysis in ruminants Domestic Animal Endocrinology 7 111-124

Hooper SB, Walker DW and Thorburn GD (1986) Oxytocin, oxytocinassociated neurophysin, and prostaglandin $F_{2 \alpha}$ concentrations in the utero-ovarian vein of pregnant and non-pregnant sheep Endocrinology 119 2590-2597

Ivell R and Richter D (1984) The gene for the hypothalamic peptide hormone oxytocin is highly expressed in the bovine corpus luteum: biosynthesis, structure and sequence analysis EMBO Journal 3 2351-2354

Ivell R, Brackett KH, Fields MJ and Richter D (1985) Ovulation triggers oxytocin gene expression in the bovine ovary FEBS Lett 190863 867

Jones DSC and Flint APF (1988) Concentrations of oxytocin-neurophysin prohormone mRNA in the corpus luteum of sheep during the oestrous cycle and in early pregnancy Journal of Endocrinology 117409 414

Koligan KB and Stormshak F (1976) Progesterone synthesis by ovine fetal cotyledons in vitro. Journal of Animal Science 42 439-443

Lioutas C, Einspanier A, Kascheike B, Walther N and Ivell R (1997) An autocrine progesterone positive feedback loop mediates oxytocin upregulation in bovine granulosa cells during luteinization Endocrinology 138 5059-5062

Morgan GL, Geisert RD, McCann JP, Bazer FW, Ott TL, Mirando MA and Stewart M (1993) Failure of luteolysis and extension of the interestrous interval in sheep treated with the progesterone antagonist mifepristone (RU 486) Journal of Reproduction and Fertility 98 451-457

Orwig KE, Bertrand JE, Ou BR, Forsberg NE and Stormshak $F$ (1994) Involvement of protein kinase-C, calpains and calpastatin in prostaglandin $\mathrm{F}_{2 \alpha}$-induced oxytocin secretion from the bovine corpus luteum Endocrinology 134 78-82

Philbert D (1984) RU-3486: an original multi-faceted anti-hormone in vivo. In Adrenal Steroid Antagonism pp 77-101 de Gruyter, New York

Pleim ET, Cailliau PJ, Weinstein MA, Etgen AM and Barfield RJ (1990) Facilitation of receptive behavior in estrogen-primed female rats by antiprogestin, RU 486 Hormones and Behavior 24 301-310

Rothchild I (1981) The regulation of the mammalian corpus luteum Recent Progress in Hormone Research 37 183-298 
Rothchild I (1996) The corpus luteum revisited: are the paradoxical effects of RU 486 a clue to how progesterone stimulates its own secretion? Biology of Reproduction 55 1-4

Salli U, Supancic S and Stormshak F (2000) Phosphorylation of myristoylated alanine-rich $\mathrm{C}$ kinase substrate (MARCKS) protein is associated with bovine luteal cell oxytocin exocytosis Biology of Reproduction 63 $12-20$

Schallenberger E, Schams D, Bullermann B and Walters DL (1984) Pulsatile secretion of gonadotrophins, ovarian steroids and ovarian oxytocin during prostaglandin-induced regression of the corpus luteum in the cow Journal of Reproduction and Fertility 71 493-501

Schams D (1983) Oxytocin determination by radioimmunoassay III. Improvements to subpicogram sensitivity and applications to blood levels in cyclic cattle Acta Endocrinologica (Copenhagen) 103 180-183

Sheldrick EL and Flint APF (1983) Luteal concentrations of oxytocin decline during early pregnancy in the ewe Journal of Reproduction and Fertility 68 477-480

Skinner DC, Bouchard P and Caraty A (1999) The progesterone blockade of the luteinizing hormone surge is overcome by RU 486 Journal of Neuroendocrinology 11 637-641
Smith GW, Gentry PC, Long DK, Bao B, Roberts RM and Smith MF (1995) Expression of progesterone receptor mRNA within ovine post-surge follicles and corpora lutea Biology of Reproduction 52 Supplement 1 151

Voss AK and Fortune JE (1993) Estradiol-17 $\beta$ has a biphasic effect on oxytocin secretion by bovine granulosa cells Biology of Reproduction 48 1404-1409

Wathes DC and Swann RW (1982) Is oxytocin an ovarian hormone? Nature 297 225-227

Webb R, Mitchell MD, Falconer J and Robinson JS (1981) Temporal relationships between peripheral plasma concentrations of oxytocin, progesterone and 13,14-dihydro-15-keto prostaglandin $F_{2 \alpha}$ during the oestrous cycle and early pregnancy in the ewe Prostaglandins 22 443453

Received 19 June 2002.

First decision 2 September 2002.

Revised manuscript received 3 October 2002.

Accepted 24 October 2002. 